The first earthquake had a depth probably greater than normal, and the second was an aftershock of the first. Both shocks happened in an acknowledged seismic zone.

\section{Exhibitions of Photography in Science and Industry}

THE Association of Scientific Workers is arranging an exhibition, "Photography in Science and Industry", to be held during November in the rooms of the Royal Photographic Society at 16 Princes Gate, London, S.W.7. The exhibition will be opened by Sir Robert Watson Watt, president of the Association, under the chairmanship of Mr. D. McMaster, president of the Royal Photographic Society, on October 31 at 3 p.m. The field covered by the exhibits will be wide and have particular reference to the war effort, including work on machine movement analysis, radiography of castings, etc., mapping and surveying, mass examination for tuberculosis, crystallography, astronomy, nuclear physics, template making, etc. Exhibitors include the Ministry of Information, technical branches of the three Services, individual technicians and the large photographic firms. During the last decade a number of specialized photographic techniques of application to industrial problems have been developed, but although the results, published in technical journals, have become familiar to many workers, the number of people employing photography as an industrial tool is still small. It is hoped that the Exhibition will do much to familiarize engineers, scientific workers, medical men and others with the methods used by specialists, and suggest their use as a direct contribution to the war effort in fields other than those illustrated. During the course of the exhibition, lectures will be given on various applications of photography; the Royal Photographic Society is arranging a symposium on industrial radiography to be held on November 21 at 2.30 p.m., and the Society's Hurter and Driffield Memorial Lecture will be delivered by Dr. S. O. Rawling on "Sensitometry since Hurter and Driffield", on November 28 at 3 p.m.

An exhibition of photographs and apparatus showing "Photography's Part in the War" will be opened by the Right Hon. Lord Brabazon of Tara, at Kodak House, Kingsway, W.C.2, on November 3. The exhibition will be open to the public at 2 p.m. on that day, and on weekdays $9.30-5.30$, Saturdays 9.30-12.30, for three weeks. Admission is free. Among the subjects illustrated are aerial reconnaissance, applications of photomicrography, high-speed photography, slow-motion cinematography, industrial radiography, photo-elastic analysis, mass radiography against tuberculosis, and the production of Airgraph letters.

\section{Exhibition of Soviet Life in War and Peace}

Soviet medicine and health services will be strongly featured in the National Exhibition of Soviet Life in War and Peace which will be held at the Wallace Collection, Hertford House, London, W.1, during November 8-22. Ten national organizations, in addition to the Ministry of Information, have co-operated in the production of the Exhibition, which will be opened by M. Maisky, the Soviet Ambassador, and Sir Edwin Lutyens, the president of the Royal Academy. It is designed to give a comprehensive picture of the life of the Soviet people from 1917 onwards. The great achievements which have been made will be recorded, and there will be displays of Soviet costumes, books, pottery, etc. In dramatic contrast to the sections devoted to peace-time developments will be those illustrating the epic feats and tremendous sacrifices made by our Russians. There will be daily film shows, music recitals and lectures. Among those contributing to the programmes are Prof. A. V. Hill, Dr. Joan McMichael, Dr. Walton, Profs. H. Levy and C. H. Reilly. Full details can be obtained from the Secretary, 150 Premier House, Southampton Row, W.C.1.

\section{Chemical Society Research Fund}

Hrtherto, the Research Fund Committee of the Chemical Society has met in December of each year to consider applications for grants from the Research Fund. In view of present conditions, however, the Council has decided that for the present, applications for grants shall be considered as and when received. Forms of application for grants are obtainable from the General Secretary. All those who have received grants, accounts of which have not been closed, are reminded that reports should be sent to the General Secretary not later than Monday, November 16.

\section{The Night Sky in November}

NEw moon occurs on Novermber 8d. 15h. 19m. U.T., and full moon on November 22d. 20h. $24 \mathrm{~m}$. Conjunctions during the month are as follows: Nov. 7d. 13h., Mercury in conjunction with the moon, Mercury $3^{\circ} \mathrm{S}$.; Nov. 10d. 10h., Mercury in conjunction with Mars, Mercury $\mathrm{I} \cdot \mathrm{I}^{\circ} \mathrm{N}$.; Nov. 23d. 15h., Saturn in conjunction, with the moon, Saturn $3^{\circ} \mathrm{N}$.; Nov. 27d. 12h., Jupiter in conjunction with the moon, Jupiter $3^{\circ} \mathrm{N}$. Occultations of stars brighter than mag. 6 are given below :

$\begin{array}{cccc} & \text { d. } & \text { h. } & \text { m. } \\ \text { Nov. } & 14 & 20 & 38 \cdot 1 \\ \text { " } & 16 & 21 & 19 \cdot 7 \\ \text { ” } & 17 & 22 & 59 \cdot 2 \\ \text { " } & 18 & 00 & 36 \cdot 2 \\ \text {, } & 20 & 01 & 30 \cdot 5\end{array}$

29 Capricorni
83 Aquaril $m$
27 Piscium
29 Piscium
Piscium

Mercury can be observed in the morning at the beginning of the month. Venus and Mars are too near the sun to be favourably observed. Jupiter can be observed soon after 10 p.m. and Saturn shortly after sunset. The Leonid meteor shower is due on Nov. 13-14, the radiant point being at R.A. 10h., Dec. $+22^{\circ}$, and the Andromedes on Nov. 18-24; the radiant is near R.A. 1 . $40 \mathrm{~m}$., Dec. $+43^{\circ}$ about the middle of this period, west of $\gamma$ Andromedæ, but neither of these showers which were once quite conspicuous displays has shown much activity in recent years.

\section{Royal Society of Edinburgh: New Officers}

At the annual meeting of the Royal Society of Edinburgh held on October 26, the following officers were elected : President: Prof. E. T. Whittaker; General Secretary : Prof. James P. Kendall ; Secretaries to Ordinary Meetings: Prof. R. J. D. Graham and Prof. W. M. H. Greaves ; Treasurer : Sir Ernest Maclagan Wedderburn; Curator of Library and Museum : Dr. John E. Mackenzie; Councillors : Prof. Edward Hindle, Prof. J. R. Matthews, Sir Arthur Olver, Dr. David Russell, Dr. Robert Campbell, the Right Hon. Lord Cooper, Prof. E. W. H. Cruickshank, Sir J. Donald Pollock, Mr. Stanley Cursiter, Dr. Douglas Guthrie, Prof. J. W. Heslop Harrison, Mr. Andrew W. Young. 